\title{
Diet preferences of the Aglajidae: a family of cephalaspidean gastropod predators on tropical and temperate shores
}

\author{
ANDREA ZAMORA-SILVA AND MANUEL ANTÓNIO E. MALAQUIAS \\ Phylogenetic Systematics and Evolution Research Group, Department of Natural History, University Museum of Bergen, University \\ of Bergen, PB 7800, 5020-Bergen, Norway
}

\begin{abstract}
Aglajidae is a family of tropical and temperate marine Cephalaspidea gastropod slugs regarded as active predators. In order to better understand their food habits and trophic interactions, we have studied the diet of all genera through the examination of gut contents. Specimens were dissected for the digestive tract and gut contents were removed and identified by optical and scanning electron microscopy. Our results confirmed that carnivory is the only feeding mode in aglajids and showed a sharp preference for vagile prey ( $94 \%$ of food items). We suggest that the interaction between crawling speed, presence of sensorial structures capable of detecting chemical signals from prey, and unique features of the digestive system (e.g. lack of radula, eversion of the buccal bulb, thickening of gizzard walls) led aglajid slugs to occupy a unique trophic niche among cephalaspideans, supporting the hypothesis that dietary specialization played a major role in the adaptive radiation of Cephalaspidea gastropods.
\end{abstract}

Keywords: aglajids, Cephalaspidea, Mollusca, predation, trophic ecology

Submitted 9 February 2015; accepted 29 April 2015; first published online 4 August 2015

\section{INTRDDUCTION}

Aglajidae is a diverse group of predominantly shallow-water cephalaspidean gastropods with an extensive degree of morphological and colour variation (Rudman, 1971, 1972a, b, c, 1974, 1978; Gosliner, 1980, 2008). The family contains seven recognized genera and approximately 80 species worldwide distributed in tropical, sub-tropical and temperate shores. They are mostly found in soft bottom habitats and alga tufts around rocky shores, coral reefs and seagrass meadows (Thompson, 1977; Martínez et al., 1993; Nakano, 2004; Valdés et al., 2006; Gosliner et al., 2008; Camacho-García et al., 2013; Costello et al., 2013; Bouchet, 2014; Malaquias, 2014).

A recent phylogenetic hypothesis of the Aglajidae confirmed the monophyly of the genera Aglaja, Melanochlamys, Nakamigawaia, Navanax, Odontoglaja and Philinopsis but suggested the paraphyly of Chelidonura which branched in three subclades (Camacho-García et al., 2013). The general morphology and anatomy of several species in these three subclades are well known and they all depict similar body plans (Rudman, 1974; Gosliner, 1980; Yonow, 1992, 1994; Ornelas-Gatdula et al., 2012). As a consequence, the taxonomic status of Chelidonura is presently not clear and thus, for the purpose of this research, we adopted its traditional definition (sensu Burn \& Thompson, 1998).

In addition to these seven genera, there has been some debate about the validity and inclusion in the family

Corresponding author:

A. Zamora-Silva

Email: Andrea.Zamora@um.uib.no
Aglajidae of three other lineages, namely Noalda, Pseudophiline and Spinoaglaja. The genus Spinoaglaja was proposed for western Atlantic species with a spine-like extension on the anterior part of the shell (Ortea et al., 2007), but Camacho-García et al. (2013) have regarded it as a synonym of Philinopsis; the latter authors did not consider Noalda as part of the Aglajidae, but this remains to be tested in a molecular phylogenetic framework. Pseudophiline has morphological similarities with Philine (Gosliner, 1980; Kitao \& Habe, 1982) and the genus was recently ascribed to the family Philinidae based on the presence of philinid-like gizzard plates and radula (Chaban, 2011). More recently, the new genus Migaya was proposed by Ortea et al. (2014) for the western Atlantic species Aglaja felis, but the validity of this genus remains to be tested in a phylogenetic framework.

Herbivory is considered the plesiomorphic feeding condition in the Cephalaspidea (Jensen, 1994; Mikkelsen, 1996; Göbbeler \& Klussmann-Kolb, 2009; Malaquias et al., 2009), and carnivory was suggested by Malaquias et al. (2009) to have arisen independently two or three times in different lineages. The latter authors have hypothesized that dietary specialization played a major role in the adaptive radiation of Cephalaspidea gastropods and that relations between prey structure, habitat and anatomy were important in the diversification within each lineage, allowing the development of more specific predator-prey interactions.

Aglajids show several unique evolutionary traits with potential relevance for feeding strategies and diversification, such as the reduction and posterior internalization of the shell, simplification of the digestive system (e.g. loss of hard mastication 

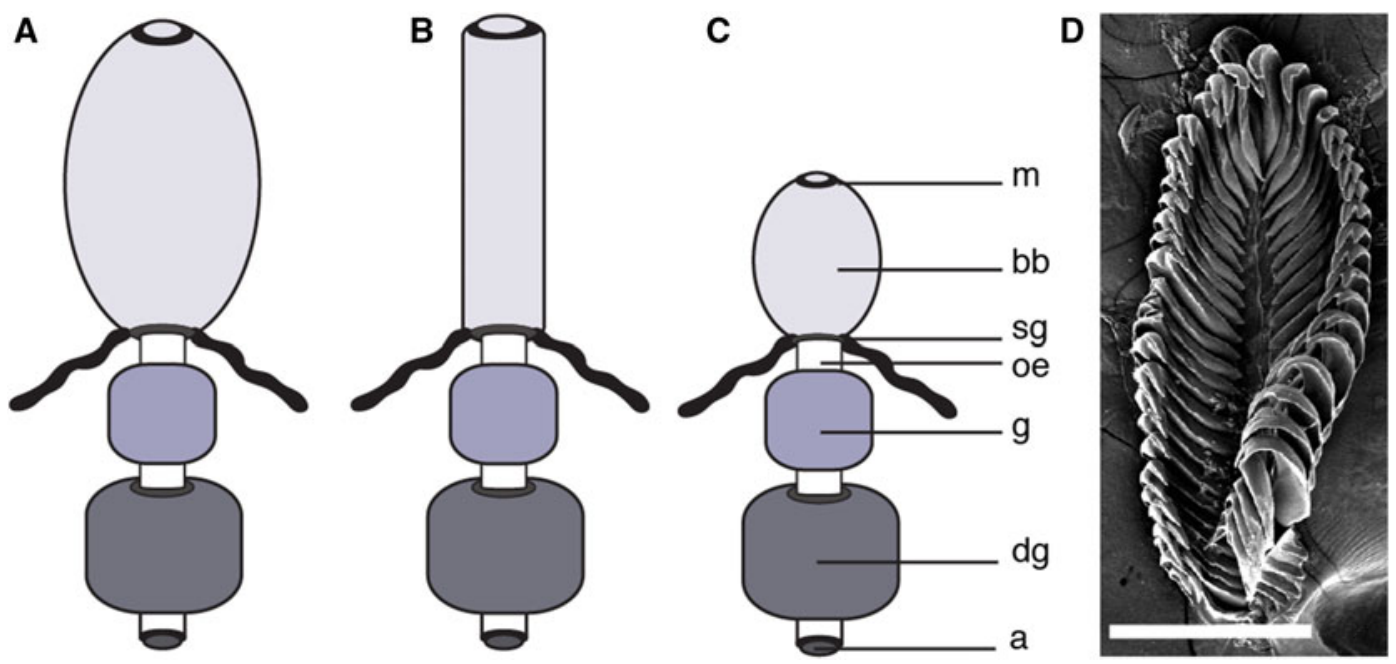

Fig. 1. Diagrammatic representation of the digestive system in Aglajidae and SEM image of the radula of Odontoglaja guamensis: (A) massive buccal bulb of Aglaja, Melanochlamys, Navanax and Philinopsis; (B) tubular buccal bulb variation of Philinopsis; (C) reduced buccal bulb in Chelidonura, Nakamigawaia and Odontoglaja; (D) radula of O. guamensis. (m) mouth; (bb) buccal bulb; (sg) salivary glands; (oe) oesophagus; (g) gut; (dg) digestive gland; (a) anus. Scale bar: $100 \mu \mathrm{m}$.

structures like the radula and gastric plates in the large majority of species), development and thickening of the buccal bulb and gizzard, secretion of deterrent chemicals, and cephalization of sensorial organs (Rudman, 1972a, b, c, 1978; Gosliner, 1980; Sleeper et al., 1980; Leonard \& Lukowiak, 1984; Wägele \& Klussmann-Kolb, 2005; Cruz-Rivera, 2011).

Several sensory structures in gastropods (e.g. eyes, anterior lateral folds, Hancock's organs, cephalic bristles, labial palps) are known to aid in tracking mucous trails (Kohn, 1983) and for example, Paine $(1963,1965)$ and Leonard \& Lukowiak (1984) have demonstrated that active predation in Navanax involves mucous trail and chemoreception. The few empirical data available on the crawling speed of aglajids suggests that they are among the fastest moving sea slugs (Turner, 1978).

The size of the buccal bulb and its ability of eversion are also important features in feeding: in Aglaja, Melanochlamys, Navanax and Philinopsis, the buccal bulb occupies almost half of the body length; while in Chelidonura, Nakamigawaia and Odontoglaja it is reduced to one-fifth of the body (Rudman, 1971). Two different forms of the buccal bulb prevail in Philinopsis: the typical bulbous shape (e.g. P. taronga, P. orientalis) that is also present in Aglaja, Melanochlamys and Navanax; and a tubular variation (e.g. P. depicta, P. pilsbryi) (Rudman, 1971, 1972a, b, c, 1974, 1978) (Figure 1A-C). The buccal bulb in Aglaja and Navanax can evert completely, whereas this ability is absent in Chelidonura, Nakamigawaia, Melanochlamys and Philinopsis (Rudman, 1971, 1974; Gosliner, 1980, 1994).

The genus Navanax feed upon other cephalaspideans including conspecifics, sacoglosans, anaspideans, nudibranchs, caenogastropods, polychaetes, crustaceans and small fish (Paine, 1963, 1965; Blair \& Seapy, 1972; Gosliner, 1980; Leonard \& Lukowiak, 1984; Pennings, 1990; Pennings et al., 2001; Korb, 2003); Philinopsis and Melanochlamys feed upon cephalaspideans and polychaetes (Rudman, 1972a, b, Göbbeler \& Klussmann-Kolb, 2009); Chelidonura upon flatworms (Gosliner, 1987, 1994; Yonow, 1992; Mangubhai, 2007); while Odontoglaja feeds on polychaetes and bivalves (Rudman, 1978; Wägele \& Klussmann-Kolb, 2005; Lobo-da-Cunha et al., 2009). No data are available on the diet of Aglaja and Nakamigawaia.
In this study we provide the first assessment of the dietary habits of Aglajidae sea slugs based on a comprehensive review of the literature and examination of gut contents of specimens representing the generic diversity of the family. We discuss our findings in relation to the distinctive anatomical, ecological and behavioural adaptations of these slugs.

\section{MATERIALS AND METHODS}

Ninety-two specimens belonging to 32 species of Aglajidae were dissected and their gut contents removed and examined (Table 1). Buccal bulb, oesophagus, intestine, and digestive gland were extracted and opened and the contents spread in Petri dishes filled with $70 \%$ ethanol and identified to the lowest possible taxonomic level using stereo, compound and scanning electron microscopy (SEM). Food items were mounted on SEM metallic stubs and coated with gold-palladium. Macrophotography was also used when convenient (Figures 2-4). In addition to gut content analyses, we revised the literature for records of Aglajidae food preferences in the wild (Table 2).

Food items were classified in 'sessile' and 'vagile' according to their mobility capacities (Menge et al., 1994; Wägele, 2004; Madden et al., 2008) and an estimate of food preference (vagile $v s$ sessile) was inferred based on the total diversity of food items recognized during this study and from literature records presented in Table 2.

\section{RESULTS}

Food items were found in the gut of 11 out of the 32 species studied and in 24 of the 92 specimens dissected, corresponding to $26 \%$ of the specimens analysed (Table 1 ): one specimen of Aglaja and Nakamigawaia, three specimens of Navanax, four specimens of Chelidonura, Philinopsis and Odontoglaja, and seven of Melanochlamys.

Based on literature records and our own results, 70 different food items were recognized belonging to 20 major taxonomic groups, with vagile organisms accounting for $94 \%$ (=66 food items) of the diet composition. Carnivory is 
Table 1. List of Aglajidae species dissected for gut contents. Numbers in brackets are the total number of specimens dissected. (ZMBN - Natural History Collections, University Museum of Bergen, Norway; WAM Western Australian Museum; USNM - United States National Museum, Smithsonian; CNMO - Colección Nacional de Moluscos, National Autonomous University of México; NMVF - Museum Victoria, Australia).

\begin{tabular}{|c|c|c|c|c|c|}
\hline Species dissected [no. of specimens dissected] & Species with gut content & No. of specimens with gut content & Voucher No & Food item & No. of food items in the gut \\
\hline \multicolumn{6}{|l|}{ Aglaja Renier, 1807} \\
\hline $\begin{array}{l}\text { A. felis Er. Marcus \& Ev. Marcus, } 1970 \text { [11] } \\
\text { A. tricolorata Renier, } 1807[1] \\
\text { Aglaja sp. }\end{array}$ & A. felis & 1 of 11 & ZMBN 84913 & Foraminiferans & 4 \\
\hline \multicolumn{6}{|l|}{ Chelidonura A. Adams, 1850} \\
\hline C. africana Pruvot-Fol, 1953 [1] & C. fulvipunctata & 1 of 6 & WAM S80134 & Nuculidae (Bivalvia) & 1 \\
\hline $\begin{array}{l}\text { C. amoena Bergh, } 1905 \text { [2] } \\
\text { C. berolina Er. Marcus \& Ev. Marcus, } 1970 \text { [2] }\end{array}$ & C. inornata & 1 of 4 & ZMBM 94027 & Chelidonura inornata & 1 \\
\hline C. cubana Ortea \& Martínez, $1997[2]$ & & & & Stylocheilus longicaudus & 1 \\
\hline C. electra Rudman, 1970 [1] & & & & (Anaspidea gastropods) & \\
\hline C. fulvipunctata Baba, 1938 [6] & & & & & \\
\hline $\begin{array}{l}\text { C. hirundinina (Quoy \& Gaimard, 1833) [1] } \\
\text { C. inornata Baba, } 1949[4]\end{array}$ & C. sandrana & 2 of 4 & ZMBM 94028 & $\begin{array}{l}\text { Philinopsis sp. } \\
\text { (Cephalaspidea gastropods) }\end{array}$ & 1 \\
\hline C. pallida Risbec, $1951[1]$ & & & & Retusa sp. & 1 \\
\hline C. sandrana Rudman, 1973 [4] & & & & (Cephalaspidea gastropods) & \\
\hline C. tsurugensis Baba \& Abe, $1964[1]$ & & & & & \\
\hline C. varians Eliot, $1903[1]$ & & & & & \\
\hline Chelidonura sp. [2] & & & & & \\
\hline \multicolumn{6}{|l|}{ Melanochlamys Cheeseman, 1881} \\
\hline M. cylindrica Cheeseman, 1881 [1] & M. diomedea & 7 of 8 & USNM & Enoploidea (Nematoda) & 5 \\
\hline M. diomedea (Bergh, 1893) [8] & & & 771859 & Kinorhyncha & 2 \\
\hline & & & & Aciculata (Polychaeta) & 2 \\
\hline \multicolumn{6}{|l|}{ Nakamigawaia Kuroda \& Habe, 1961} \\
\hline $\begin{array}{l}\text { N. spiralis Kuroda \& Habe, } 1961 \text { [7] } \\
\text { Nakamigawaia sp. [2] }\end{array}$ & N. spiralis & 1 of 7 & ZMBM 94029 & Foraminiferans & 3 \\
\hline \multicolumn{6}{|l|}{ Navanax Pilsbry, 1895} \\
\hline N. aenigmaticus (Bergh, 1893) [3] & N. aenigmaticus & 2 of 3 & USNM 734396 & $\begin{array}{l}\text { Bulla punctulata } \\
\text { (Cephalaspidea gastropods) }\end{array}$ & 3 \\
\hline $\begin{array}{l}\text { N. inermis (J.G. Cooper, 1863) [4] } \\
\text { N. orbygnianus (Rochebrune, 1881) [2] }\end{array}$ & N. inermis & 1 of 4 & CNMO 1818 & Gobiidae (Pisces) & 1 \\
\hline \multicolumn{6}{|l|}{ Noalda Iredale, 1936} \\
\hline N. exigua (Hedley, 1912) [1] & - & - & - & - & - \\
\hline \multicolumn{6}{|l|}{ Odontoglaja Rudman, 1978} \\
\hline \multirow[t]{3}{*}{ O. guamensis Rudman, 1978 [4] } & O. guamensis & 4 of 4 & ZMBM 94030 & $\begin{array}{l}\text { Philine sp. } \\
\text { (Cephalaspidea gastropods) }\end{array}$ & 2 \\
\hline & & & & Isopoda & 1 \\
\hline & & & & $\begin{array}{l}\text { Holothuroidea } \\
\text { (Echinodermata) }\end{array}$ & 1 \\
\hline \multicolumn{6}{|l|}{ Philinopsis Pease, 1860} \\
\hline $\begin{array}{l}\text { P. depicta Pease, } 1860[3] \\
\text { P. falciphallus Gosliner, } 2011 \text { [5] }\end{array}$ & P. depicta & 2 of 3 & ZMBM 94031 & $\begin{array}{l}\text { Facelinidae } \\
\text { (Nudibranchia gastropods) }\end{array}$ & 1 \\
\hline
\end{tabular}




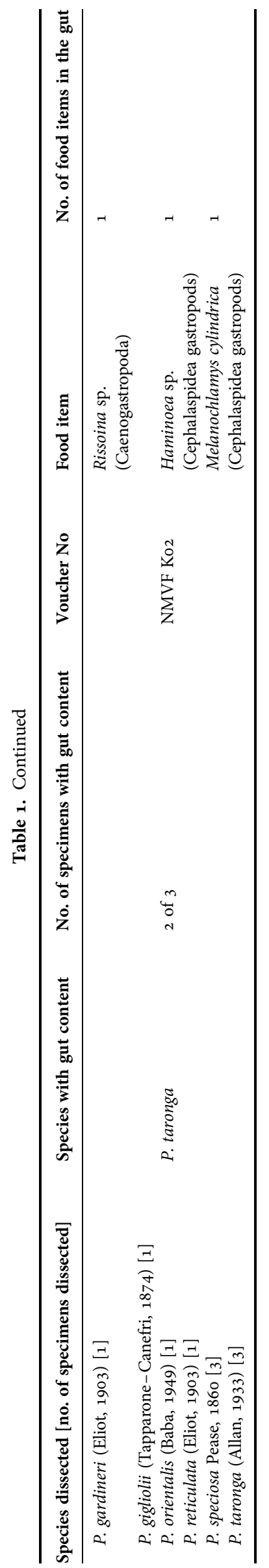

confirmed as the only feeding strategy in Aglajidae. The sessile organisms recognized in the gut of aglajids were bivalves, foraminiferans and sponge spicules (Table 2).

Foraminiferans were the only food item found in the gut contents of Aglaja and Nakamigawaia, whereas Navanax yielded the most diverse assemblage of food items, namely sponges, cephalaspidean gastropods, nudibranch gastropods, sacoglossan gastropods, caenogastropods, annelids, crustaceans and fish.

Field observations showed that Chelidonura inornata feed upon conspecifics and Navanax inermis was observed sucking in juveniles of Aplysia sp. (A. Zamora, personal observation).

\section{DISCUSSIDN}

With the exception of the studies by Paine $(1963,1965)$ on the diet of the genus Navanax, knowledge about dietary preferences of aglajid slugs is based on sparse records included in general works about the diversity or morphological aspects of the Aglajidae (e.g. Tchang-Si, 1934; Marcus, 1961; Marcus \& Marcus, 1966; Blair \& Seapy, 1972; Rudman, 1972a, b, 1978; Pennings, 1990; Pennings et al., 2001; Padilla et al., 2010; Gosliner, 2011; Camacho-García et al., 2013; see Table 2). This study is the first comprehensive account dedicated to understand the trophic interactions of Aglajidae slugs as a whole.

The rather low percentage of slugs found with food remains in the gut $(26 \%)$ may be partly explained by the fact that some aglajids regurgitate the hard parts of prey items after digestion when those seem to be above a certain threshold size. This behaviour was documented by Rudman (1971, 1972a) for the species Philinopsis speciosa, which he observed regurgitating several empty shells of the gastropod Bulla ampulla after 2-3 h of capture. Aglajids do not have a crushing gizzard with plates and in some cases large shells are likely too difficult to be carried along the digestive tract and end up, therefore, being regurgitated. However, Paine (1963) and Pennings (1990) have demonstrated that in the large sized-body aglajid species Navanax inermis (average adult size c. $40 \mathrm{~mm}$; Leonard \& Lukowiak, 1984), complete shells of small 'prosobranchs' and 'opisthobranchs' (e.g. Aplysia, Bulla) and hard-parts of sea slugs (e.g. radulae, jaws, shells) can be defecated unaltered.

A striking result of this research is the recognition that aglajids feed nearly exclusively upon vagile prey ( $94 \%$ of food items; Table 2). Motile organisms secrete mucus to aid in crawling or as a protective mechanism (e.g. opisthobranchs, nematodes, platyhelminths, annelids, gastropods) (Brusca \& Brusca, 2003; Hickman et al., 1993), leaving behind mucous trails that can be located and traced by aglajids using their sensorial organs (Paine, 1965; Kohn, 1983; Davies \& Blackwell, 2007; Terrence et al., 2013).

The genera Navanax and Philinopsis include relatively large animals (adult size over $10 \mathrm{~mm}$ in most cases) with a massive buccal bulb that occupies about half of the body cavity (Rudman, 1972a, 1974) (Figure 1). These slugs are active crawlers and can feed upon larger prey (e.g. fish, bulloid gastropods, polychaetes, flatworms, crustaceans, ctenophores and other sea slugs; Table 3 ) by a rapid, partial or complete eversion of the buccal bulb. Paine (1963) documented cannibalism in Navanax ( $N$. inermis) but only between animals of dissimilar size and when those attempted to 


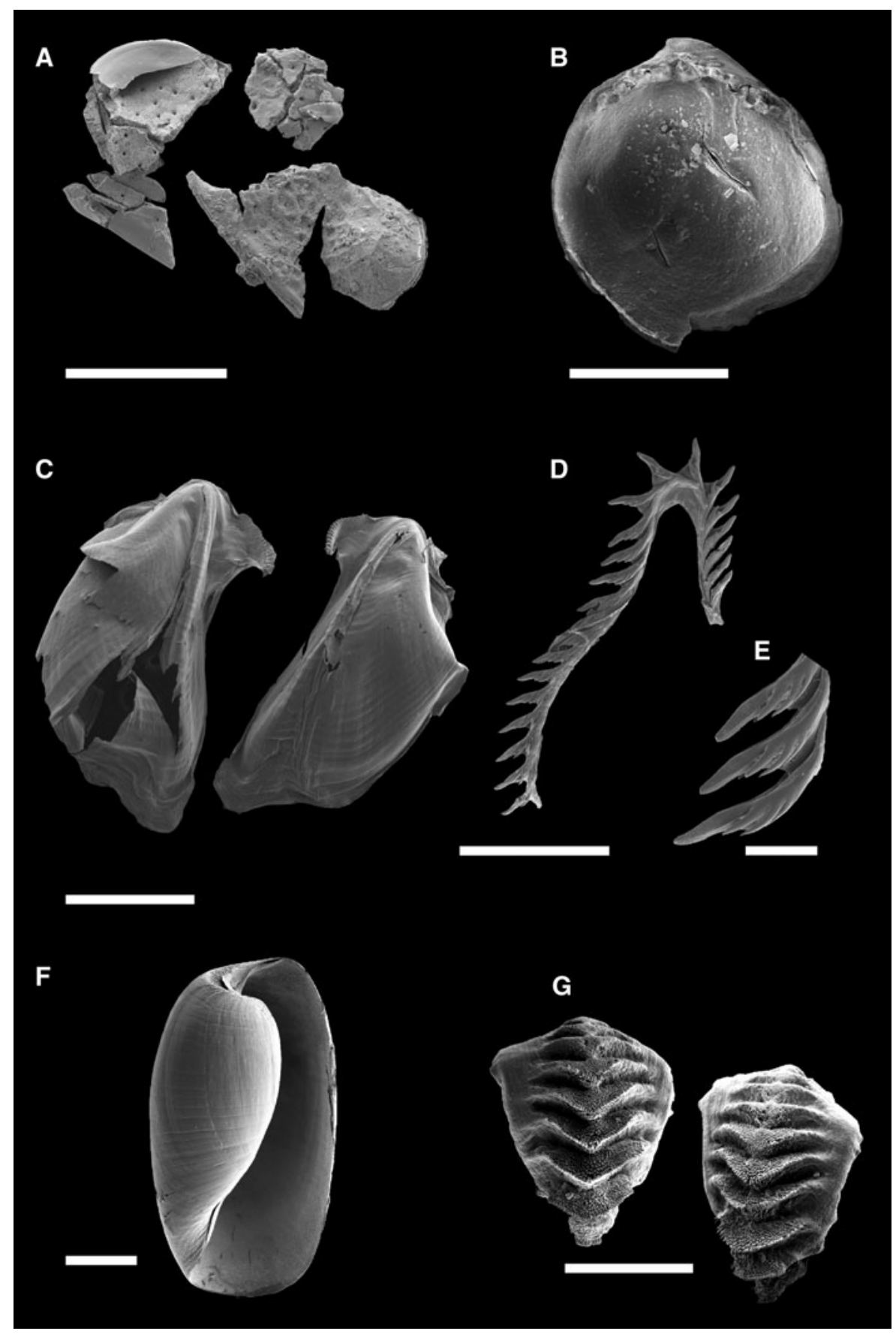

Fig. 2. Scanning electron micrographs of food items found in the digestive tract of Aglajidae specimens: (A) residues of foraminiferans in Aglaja felis ZMBN 84913; (B) valve of Nuculidae bivalve in Chelidonura fulvipunctata WAM S80134; (C) jaws of Facelinidae nudibranch in Philinopsis depicta ZMBM 94031; (D) radula of Facelinidae nudibranch in Philinopsis depicta ZMBM 94031; (E) detail of radula of Facelinidae nudibranch in Philinopsis depicta ZMBM 94031; (F) shell of Haminoea sp. in Philinopsis taronga NMVF Ko2; (G) gizzard plates of Haminoea sp. in Philinopsis taronga NMVF Ko2. Scale bars A and E: $200 \mu \mathrm{m}$; B and F: $100 \mu \mathrm{m} ; \mathrm{C}, \mathrm{D}$, and G: $20 \mu \mathrm{m}$.

mate. The diet of $N$. inermis is by far the best known among aglajids as a result of the long-term and dedicated studies by Paine (1963, 1965; see Table 2). These studies seem to indicate that the genus Navanax is the most generalist among the Aglajidae, but of course this can be the result of the uneven amount of data collected for this genus when compared with the others. The presence of sponge spicules found by us in the gut of Navanax is likely the result of random ingestion.
On the other hand, Chelidonura, Melanochlamys and Odontoglaja species are on average smaller slugs (adult size less than $10 \mathrm{~mm}$ in most cases; exceptions are common in Chelidonura) that have comparatively a reduced and non-eversible buccal bulb (the latter is partially eversible in Odontoglaja) (Rudman, 1972b, 1974; Figure 1; Table 3). Chelidonura seems to have a preference for epifaunal organisms (e.g. flatworms, slugs, shelled gastropods), whereas Melanochlamys feed predominantly upon infaunal prey such 

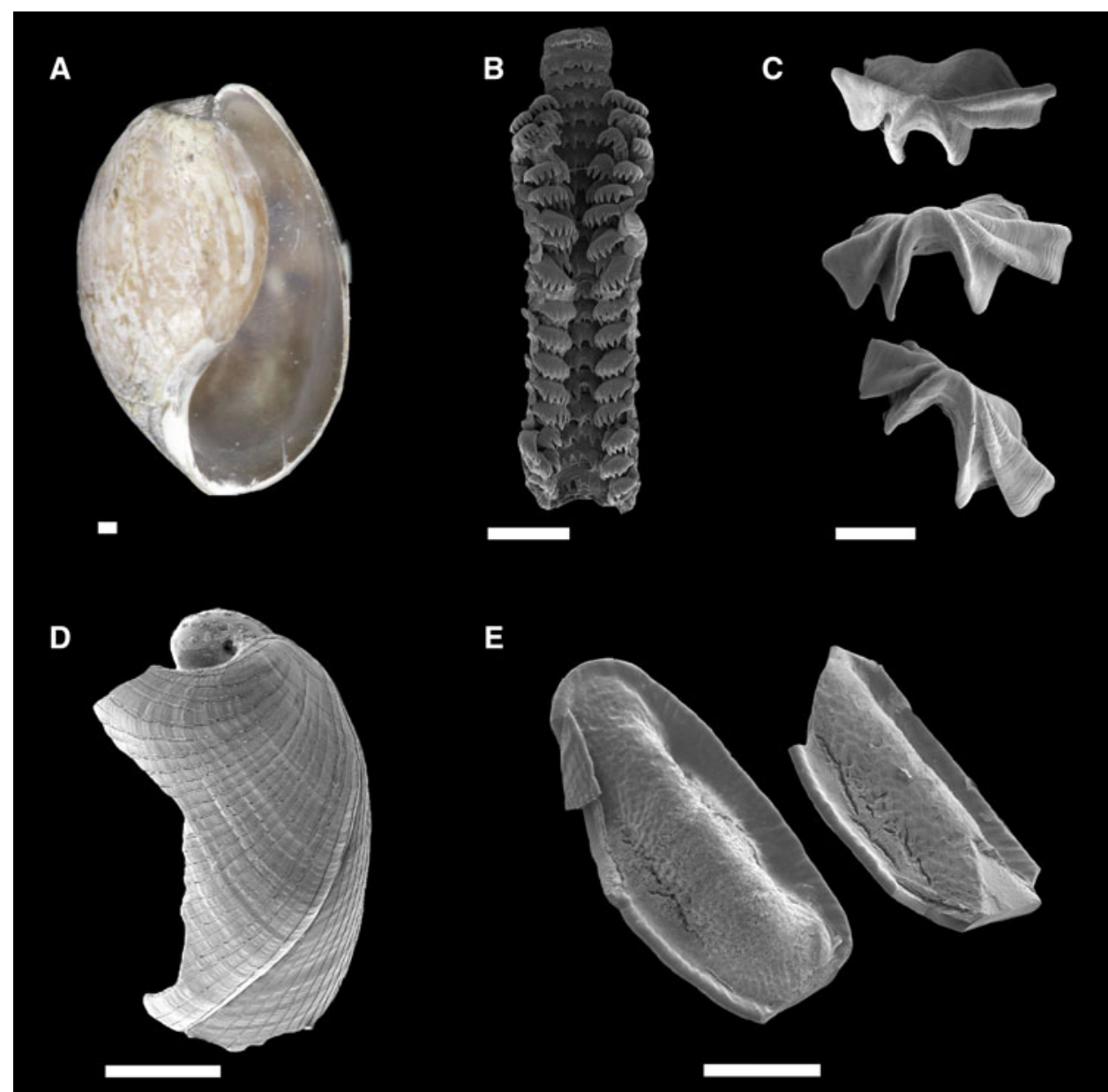

E

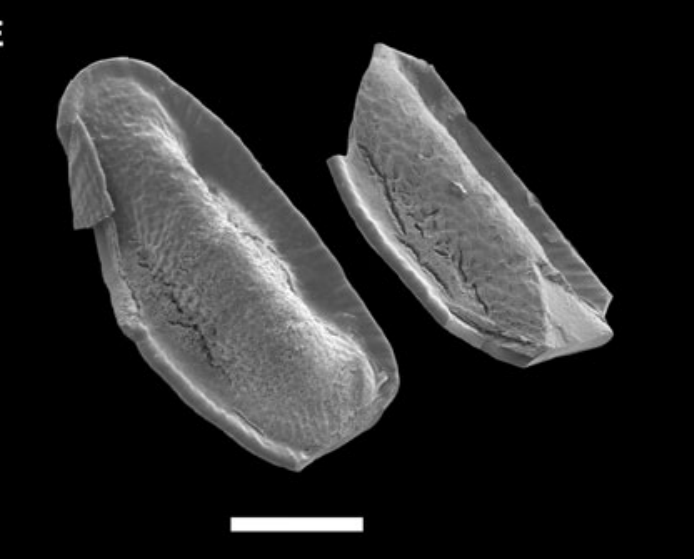

$\mathbf{F}$

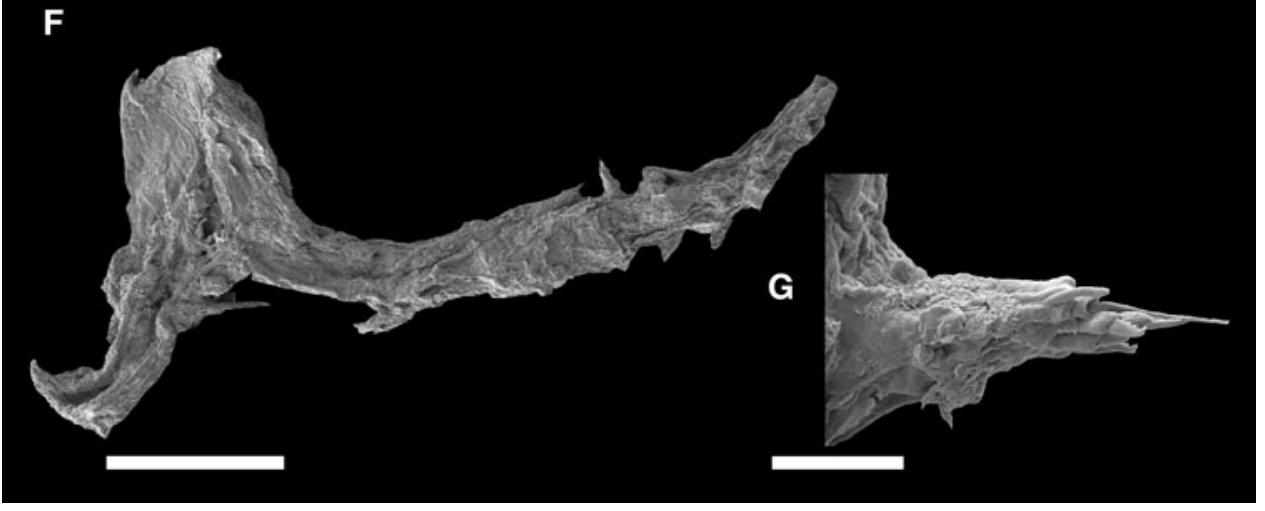

Fig. 3. Scanning electron micrographs of food items found in the digestive tract of Aglajidae specimens: (A) shell of Bulla punctulata in Navanax inermis CNMO 1818; (B) radula of B. punctulata in Navanax inermis CNMO 1818; (C) gizzard plates of B. punctulata in Navanax inermis CNMO 1818; (D) shell of Philine sp. in Odontoglaja guamensis ZMBM 94030; (E) gizzard plates of Philine sp. in Odontoglaja guamensis ZMBM 94030; (F) Aciculata polychaete in Melanochlamys diomedea USNM 771859; (G) detail of the parapodia of Aciculata polychaetes in Melanochlamys diomedea USNM 771859. Scale bars A: 1 mm; B, C and D: $200 \mu \mathrm{m}$; E and G: $20 \mu \mathrm{m}$; F: $100 \mu \mathrm{m}$.

as polychaetes, nemerteans, nematodes and kinorhynchs (Table 3).

Odontoglaja, the only confirmed genus with radula (Gosliner et al., 2008; Figure 1; referred to a possible Chelidonura with a vestigial radula), which is well developed with strong bicuspid lateral teeth (Gosliner et al., 2008; Figure 1), has apparently a preference for organisms with thicker dermis such as crustaceans, ?holothurians, and polychaetes (Hickman et al., 1993; Table 3).
Aglaja and Nakamigawaia are genera for which nothing was previously known about their diet. Most species have an average adult size over $10 \mathrm{~mm}$ (Rudman, 1972c; Baba, 1985), but based on our results it is not possible to ascertain where the sole presence of foraminiferans found in the gut reflects a dietary preference or results from accidental ingestion. Because of average size, anatomical configuration of the digestive tract, and crawling capacities of these snails (Rudman, 1972C; Baba, 1985; Gosliner et al., 2008; Figure 1; 


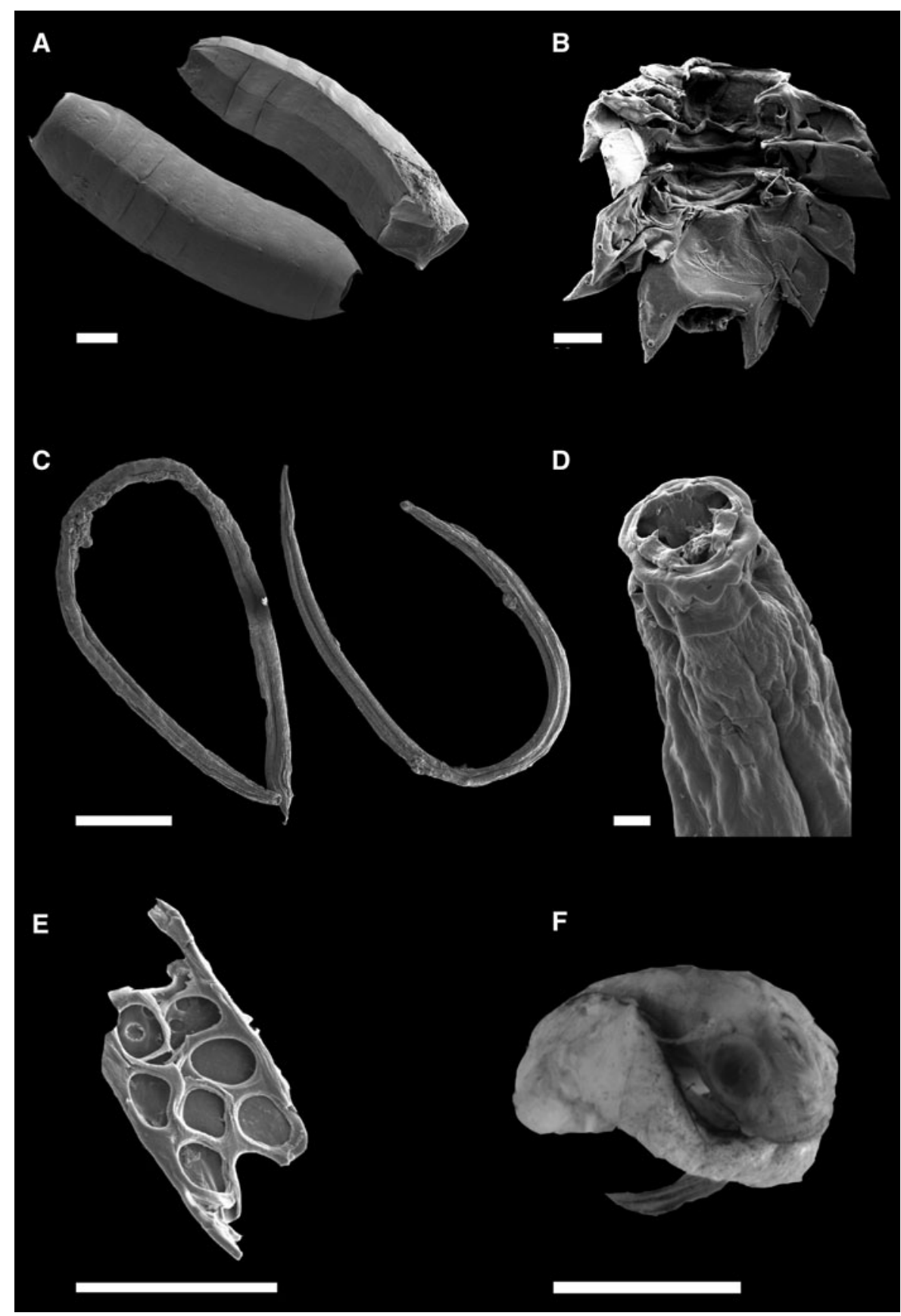

Fig. 4. Scanning electron micrographs of food items found in the digestive tract of Aglajidae specimens: (A) Kynorhyncha sp. in Melanochlamys diomedea USNM 771859; (B) ?exoskeleton of Isopoda in Odontoglaja guamensis ZMBM 94030; (C) Enoploidea nematodes in Melanochlamys diomedea USNM 771859; (D) detail of the mouth of the nematodes in Melanochlamys diomedea USNM 771859; (E) ?fragment of a spicule of Holothuria in Odontoglaja guamensis ZMBM 94030; (F) complete specimen of Gobiidae fish in Navanax inermis CNMO 1818. Scale bars A: $20 \mu \mathrm{m}$; B: $30 \mu \mathrm{m}$ : C and E: $100 \mu \mathrm{m}$; D: $10 \mu \mathrm{m}$, F: $5 \mathrm{~mm}$.

Tables 2 \& 3), our expectation was to find a diet composed by several motile invertebrates.

Malaquias et al. (2009) mapped the diet of most lineages of cephaslaspids onto a molecular phylogeny of the group and have suggested that dietary specialization played a major role in the adaptive radiation of these gastropods. Our results reinforced the view that Aglajidae slugs are the only active hunter group of cephalaspids and the only one to be specialized on motile prey (Malaquias et al., 2009; Göbbeler \& Klussmann-Kolb, 2009).

\section{ACKNDWLEDGEMENTS}

We are indebted to A. Cosgrove-Wilke (Western Australian Museum), E. Naranjo-García (Colección Nacional de Moluscos, UNAM-México), J. Chuk (Museum Victoria, Australia), N. Anthes (University of Tübingen), K. Jensen and O. Tendal (Zoologisk Museum, Copenhagen), T. Nickens (Smithsonian Institution, National Museum of Natural History), and M. Caballer (Muséum national $\mathrm{d}^{1}$ Histoire naturelle, Paris) for providing specimens for this 
Table 2. Review of the diet of Aglajidae based on literature records and novel data (based on animals collected in the wild).

\begin{tabular}{|c|c|c|c|}
\hline Species & Food item & Prey ecology & References \\
\hline \multicolumn{4}{|l|}{ Aglaja Renier, 1807} \\
\hline A. felis Er. Marcus \& Ev. Marcus, 1970 & - Foraminiferans & Sessile & Present study \\
\hline \multicolumn{4}{|l|}{ Chelidonura A. Adams, 1850} \\
\hline C. alisonae Gosliner, 2011 & - Convoluta acoels flatworms (Acoelomorpha) & Vagile & Gosliner (2011) \\
\hline C. fulvipunctata Baba, 1938 & - Nuculidae (Bivalvia) & Sessile & Present study \\
\hline \multirow[t]{3}{*}{ C. hirudinina (Quoy \& Gaimard, 1833) } & - Free living flatworms (?Acoelomorpha/Platyhelminthes) & Vagile & Gosliner (1987) \\
\hline & & & Cruz-Rivera (2011) \\
\hline & & & Kohn (1983) \\
\hline \multirow[t]{2}{*}{ C. inornata Baba, 1949} & - Chelidonura inornata (Cephalaspidea gastropods) & All vagile & Rudman, 1974 \\
\hline & - Stylocheilus longicaudus (Anaspidea gastropods) & & Present study \\
\hline C. punctata Eliot, 1903 & - Acoels flatworms & Vagile & Mangubhai (2007) \\
\hline \multirow{2}{*}{ C. sandrana Rudman, 1973} & - Philinopsis sp. & All vagile & Present study \\
\hline & - Retusa sp. (Cephalaspidea gastropods) & & \\
\hline C. varians Eliot, 1903 & - Acoels flatworms (Acoelomorpha) & Vagile & Yonow $(1992,1994)$ \\
\hline \multicolumn{4}{|l|}{ Melanochlamys Cheeseman, 1881} \\
\hline \multirow{2}{*}{ M. cylindrica Cheeseman, 1881} & - Polychaeta & All vagile & Rudman $(1971,1972 b, c)$ \\
\hline & - Nemertea & & \\
\hline \multirow[t]{3}{*}{ M. diomedea (Bergh, 1893) } & - Enoploidea (Nematoda) & All vagile & Present study \\
\hline & - Kinorhyncha & & \\
\hline & - Aciculata (Polychaeta) & & \\
\hline \multicolumn{4}{|l|}{ Nakamigawaia Kuroda \& Habe, 1961} \\
\hline N. spiralis Kuroda \& Habe, 1961 & - Foraminiferans & Sessile & Present study \\
\hline \multicolumn{4}{|l|}{ Navanax Pilsbry, 1895} \\
\hline \multirow[t]{4}{*}{ N. aenigmaticus (Bergh, 1893) } & - Haliclona sp. (Porifera) & Sessile & Ev. Marcus \& Er Marcus (1966) \\
\hline & - Tethya sp. (Porifera) & & Padilla et al. (2010) \\
\hline & - Bulla sp. & & Present study \\
\hline & - Bulla punctulata (Cephalaspidea gastropods) & Vagile & \\
\hline \multirow[t]{2}{*}{ N. gemmatus (Mörch, 1863) } & $\begin{array}{l}\text { - Platyhelminthes } \\
\text { Pla }\end{array}$ & All vagile & Thompson $(1976,1977)$ \\
\hline & - Elysia crispata (Sacoglossa gastropods) & & Gosliner, 1980 \\
\hline \multirow[t]{10}{*}{ N. inermis (J. G. Cooper, 1863) } & - Aplysia californica (Anaspidea gastropods) & All vagile & Paine $(1963,1965)$ \\
\hline & - Bulla punctulata & & Emlen (1966) \\
\hline & - B. gouldiana & & Blair \& Seapy (1972) \\
\hline & - Haminoea virescens & & Gosliner $(1980 ; 1994)$ \\
\hline & - Navanax inermis (Cephalaspidea gastropods) & & Sleeper, et al. (1980) \\
\hline & - Elysia sp. (Sacoglossa gastropods) & & Leonard \& Lukowiak (1984) \\
\hline & - Barleeia sp. (Caenogastropoda) & & Pennings (1990) \\
\hline & - Cystiscus sp. (Neogastropoda) & & Pennings et al. (2001) \\
\hline & - Gobiidae (Pisces) & & Korb (2003) \\
\hline & & & Present study \\
\hline N. polyalphos (Gosliner \& Williams, 1972) & - Haminoea sp. (Cephalaspidea gastropods) & Vagile & Gosliner \& Williams (1972) \\
\hline
\end{tabular}


Polychaeta

Philine sp. (Cephalaspidea gastropods)

Isopoda (Crustacea)

Holothuroidea (Echinodermata)

O. mosaica Gosliner, 2011

Philinopsis Pease, 1860

P. ctenophoraphaga Gosliner, 2011

P. depicta Pease, 1860

P. falciphallus Gosliner 2011

P. pilsbryi (Eliot, 1900)

P. minor (Tchang-Si, 1934)

P. speciosa Pease, 1860

P. taronga (Allan, 1933)

Aliculastrum cylindricum
Benthic copepods (Crustacea)

Coeloplana (Benthoplana) meteoris (Benthic ctenophores)

Polychaet

Philine quadripartita

P. scabra (Cephalaspidea gastropods)

Facelinidae (Nudibranchia gastropods)

Rissoina sp. (Caenogastropoda)

Polyclad flatworms (Platyhelminthes)

Small opisthobranchs (Opisthobranchia gastropods)

Small molluscs

Bulla ampulla

Chelidonura sandrana

Haminoea sp. (Cephalaspidea gastropods)

Aplysia parvula (Anaspidea gastropods)

Ringicula sp. (Heterobranchia gastropods)

- Amalda sp. (Caenogastropoda)

Haminoea sp.

Haminoea zelandiae

Melanochlamys cylindrica

- Philine auriformis (Cephalaspidea gastropods)

$\begin{array}{ll}\text { Vagile } & \begin{array}{l}\text { Rudman (1978) } \\ \text { Present study }\end{array} \\ & \\ \text { Vagile } & \text { Gosliner (2011) } \\ & \text { Gosliner (2011) } \\ \text { Vagile } & \text { Marcus (1961) } \\ \text { All vagile } & \text { Gosliner (1980) } \\ & \text { Chiu, 1990 } \\ & \text { Lobo-da-Cunha et al. (2009) } \\ & \text { Lobo-da-Cunha et al. (2011) } \\ & \text { Present study } \\ & \text { Gosliner (2011) } \\ \text { Göbbeler \& Klussmann-Kolb (2009) } & \text { Tchang-Si (1934) } \\ \text { Vagile } & \text { Rudman (1972a) } \\ \text { Vagile } & \text { Gosliner (1980) } \\ \text { Vagile } & \text { Yonow (1992) } \\ \text { All vagile } & \\ & \\ & \\ & \text { Rudman (1972a) } \\ \text { All vagile } & \text { Present study } \\ & \\ & \\ & \end{array}$


Table 3. Synoptic table of the diet preferences and buccal bulb features in the Aglajidae genera.

\begin{tabular}{lll}
\hline Genus & Buccal bulb features & Diet preferences \\
\hline Aglaja & Massive, eversible & Foraminiferans \\
Chelidonura & Reduced, non-eversible & Flatworms, slugs, shelled gastropods, 'Bivalves' \\
Melanochlamys & Massive, non-eversible & Polychaetes, Nemerteans, Nematodes, Kinorhynchs \\
Nakamigawaia & Reduced, non-eversible & Foraminiferans \\
Navanax & Massive, eversible & Shelled gastropods, flatworms, slugs, fish, 'Sponges' \\
Odontoglaja & Reduced, non-eversible & Polychaetes, shelled gastropods, Crustaceans, Holothurians \\
Philinopsis & Massive/Tubular, non-eversible & Benthic ctenophorans, Polychaetes, Shelled gastropods, Flat worms, \\
& & Slugs \\
\hline
\end{tabular}

study. We also thank J. L. Cervera (University of Cádiz), N. Budaeva (University Museum of Bergen, Norway) and P. Valentich-Scott (Santa Barbara Museum of Natural History) for helping with identification of some food items. We are grateful to E. Erichsen (University of Bergen) for his support with the electron microscopy sessions. M. Caballer made valuable comments on this paper.

\section{FINANCIAL SUPPDRT}

This work was funded through a doctoral grant given to the first author by the Consejo Nacional de Ciencia $y$ Tecnología (CONACYT-México), fellowship BAZS/18889o/ 2010. Additionally, this research benefited from specimens gathered through visits of the second author to European natural history museums funded by the SYNTHESYS Project, http://www.synthesys.info/, which is financed by the European Community Research Infrastructure Action under the $\mathrm{FP}_{7}$ 'Capacities' Program.

\section{REFERENCES}

Baba K. (1985) Anatomical review of a Cephalaspidean mollusc Nakamigawaia spiralis Kuroda \& Habe in Habe 1961, (Aglajidae), from Japan. Mukaishima Marine Biological Station, Occasional Publications, no. 231, 5 pp.

Blair G.M. and Seapy R. (1972) Selective predation and prey location in the sea slug Navanax inermis. Veliger 15, 119-124.

Bouchet P. (2014) Aglajidae Pilsbry, 1895 (1847). In World Register of Marine Species. http://www.marinespecies.org/aphia.php?p=taxdetails \&id= 22981 .

Brusca R.C. and Brusca G.J. (2003) Invertebrates, 2nd edn. Sunderland, MA: Sinauer Associates.

Burn R. and Thompson T.E. (1998) Order Cephalaspidea. In Beesley P.L., Ross G.J.B. and Wells A. (eds) Mollusca, the Southern synthesis, fauna of Australia Part B. Melbourne: CSIRO Publishing, pp. 943-959.

Camacho-García Y.E., Ornelas-Gatdula E., Gosliner T.M. and Valdés Á. (2013) Phylogeny of the family Aglajidae (Pilsbry 1895) (Heterobranchia: Cephalaspidea) inferred from mtDNA and nDNA. Molecular Phylogenetics and Evolution 71, 113-126.

Chaban E.M. (2011) Philinorbis teramachi Habe, 1950 (Gastropoda: Opisthobranchia: Cephalaspidea) from coastal waters of Vietnam. In Lutaenko K.A. (ed.) Proceedings of the workshop Coastal marine biodiversity and bioresources of Vietnam and adjacent areas to the South China Sea, Zhirmundsky Institute of Marine Biology, Far Eas Branch of the Russian Academy of Sciences, Nha Trang, 24-25
November 2001. Vietnam: Asia-Pacific Network for Global Change Research (APN), pp. 37-38.

Chiu S.T. (1990) The diet, prey size and consumption of Philine orientalis (Opisthobranchia: Philinidae) in Hong Kong. Journal of Molluscan Studies 56, 289-299.

Costello M.J., Bouchet P., Boxshall G., Fauchald K., Gordon D., Hoeksema B.W., Poore G.C.B., van Soest R.W.M., Sto S., Walter T.C., Vanhoorne B., Decock W. and Appeltans W. (2013) Global coordination and standardisation in Marine biodiversity through the World Register of Marine Species (WoRMS) and related databases. PLoS ONE 8, e51629. doi: 10.1371/journal.pone.0051629.

Cruz-Rivera E. (2011) Evidence for chemical defense in the cephalaspidean Nakamigawaia spiralis Huroda and Habe 1961. Proceedings of the Malacological Society of London 77, 95-97.

Davies M. and Blackwell J. (2007) Energy saving through trail following in a marine snail. Proceedings of the Royal Society of London 274, $1233-1236$.

Emlen M.J. (1966) The role of time and energy in food preference. American Naturalist 96, 611-617.

Göbbeler K. and Klussmann-Kolb A. (2009) Molecular phylogeny of Euthyneura (Mollusca, Gastropoda) with special focus on Opisthobranchia as a framework for reconstruction of evolution of diet. Thalassas 27, 121-154.

Gosliner T.M. (1980) Systematics and phylogeny of the Aglajidae. (Opisthobranchia: Mollusca). Zoological Journal of the Linnean Society $68,325-360$.

Gosliner T.M. (1987) Nudibranchs of Southern Africa. A guide to opisthobranch molluscs of Southern Africa. Monterey, CA: Sea Challengers and J. Hamann in association with the California Academy of Sciences.

Gosliner T.M. (1994) Gastropoda: Opisthobranchia. In Harrison F.W. and Kohn A.J. (eds) Mollusca I, Microscopy Anatomy of Invertebrates. New York, NY: Wiley-Liss, pp. 253-355.

Gosliner T.M. (2011) Six new species of aglajids opisthobranch molluscs from the tropical Indo-Pacific. Zootaxa 2751, 1-24.

Gosliner T.M., Behrens D.W. and Valdés Á. (2008) Indo-Pacific Nudibranchs and Sea Slugs. A field guide to the World's most diverse fauna. San Francisco, CA: Sea Challengers in association with the California Academy of Sciences.

Gosliner T.M. and Williams G. (1972) A new species of Chelidonura from bahía de San Carlos, Gulf of California, with a synonymy of the Family Aglajidae. Veliger 14, 424-436.

Hickman C.P., Roberts L.S. and Larson A. (1993) Integrated principles of $z o o l o g y$, and edn. St. Louis, MO: Mosby.

Jensen K. (1994) Behavioral adaptations and diet specificity of sacoglossan opisthobranchs. Ethology Ecology and Evolution 6, 87-101. 
Kitao K. and Habe T. (1982) Systematic positions of Hamineobulla kawamurai Habe 1950 and Pseudophiline hayashii Habe 1976 (Opisthobranchia). Venus 41, 61-63.

Kohn A.J. (1983) Feeding biology of gastropods. In Saleuddin A.S.M. and Wilbur K.M. (eds) The Mollusca, physiology. Part 2. London: Academic Press, pp. 3-53.

Korb R. (2003) Lack of dietary specialization in adult Aplysia californica evidence from stable carbon isotope composition. Journal of Experimental Marine Biology and Ecology 83, 501-505.

Leonard J. and Lukowiak K. (1984) An ethogram of the sea slug Navanax inermis (Gastropoda, Opisthobranchia). Tierpsychologie 65, 327-345.

Lobo-da-Cunha A., Ferreira Í., Coelho R. and Calado G. (2009) Light and electron microscopy study of the salivary glands of the carnivorous opisthobranch Philinopsis depicta (Mollusca, Gastropoda). Tissue and Cell 41, 367-375.

Lobo-da-Cunha A., Santos T., Oliveira A., Coelho R. and Calado G. (2011) Microscopical study of the crop and oesophagus of the carnivorous opisthobranch Philinopsis depicta (Cephalaspidea: Aglajidae). Journal of Molluscan Studies 77, 322-331.

Madden C., Goodin K., Allee B., Finkbeiner M. and Bamford D. (2008) Coastal and Marine Ecological Classification Standard. National Oceanic and Atmospheric Administration, U. S. Department of Commerce, Occasional Publications, no. III, pp. 46-51.

Malaquias M.A.E. (2014). New data on the heterobranch gastropods ("opisthobranchs") for the Bahamas (tropical western Atlantic ocean). Marine Biodiversity Records 7, e27.

Malaquias M.A.E., Berecibar E. and Reid D.G. (2009) Reassessment of the tropic position of Bullidae (Gastropoda: Cephalaspidea) and the importance of diet in the evolution of cephalaspidean gastropods. Journal of Zoology 277, 88-97.

Malaquias M.A.E., Mackenzie-Dodds J., Bouchet P., Gosliner T.M. and Reid D.G. (2009) A molecular phylogeny of the Cephalaspidea sensu lato (Gastropoda: Euthyneyra): Architectibranchia redefined and Runcinacea reinstated. Zoologica Scripta 38, 23-41.

Mangubhai S. (2007) Chelidonura punctata (Eliot 1903) prey on acoel flatworms recruiting onto Platygyra daedalea (Ellis and Solander 1796) in Kenya. Coral Reefs 26, 1057.

Marcus E. (1961) Opisthobranch molluscs from California. Veliger 3, 1-84

Marcus E. and Marcus E. (1966) Opisthobranchs from tropical West Africa. (The R/V Pillsbury deep sea expedition to the Gulf of Guinea 1964-1965). Studies of Tropical Oceanography, Miami 4, 152-208.

Martínez E., Ballesteros M., Ávila C. and Cimino G. (1993) La familia Aglajidae en la Península Ibérica. Iberus 11, 15-29.

Menge B., Berlow E., Blanchette C., Navarrete S. and Yamada S. (1994) The keystone species concept: variation in the interaction strength in a rocky intertidal habitat. Ecological Monographs 64, 249-286.

Mikkelsen P.M. (1996) The evolutionary relationships of Cephalaspidea s.l. (Gastropoda: Opisthobranchia): a phylogenetic analysis. Malacologia $37,375-442$.

Nakano R. (2004) Opisthobranchs of Japan Islands. Japan: Rutles Inc.

Ornelas-Gatdula E., Dupont A. and Valdés Á. (2012) The tail tells the tale: taxonomy and biogeography of some Atlantic Chelidonura (Gastropoda: Cephalaspidea: Aglajidae) inferred from nuclear and mithocondrial gene data. Biological Journal of the Linnean Society $163,1077-1095$.

Ortea J., Caballer M., Moro L. and Espinosa J. (2014) What the shell tells in Aglajidae: a new genus for Aglaja felis (Opisthobranchia: Cephalaspidea). Revista de la Academia Canaria de Ciencias 26, 83- 119
Ortea J., Moro L. and Espinosa J. (2007) Descripción de dos nuevas especies de Philinopsis Pease 1860 (Mollusca: Opisthobranchia: Cephalaspidea) de Cuba y Bahamas con comentarios sobre las especies atlánticas del género. Revista de la Academia Canaria de Ciencias 4, $33-52$.

Padilla C.J., Carballo J.L. and Camacho M.L. (2010) A qualitative assessment of sponge-feeding organisms from the Mexican pacific coast. Marine Biology 4, 39-46.

Paine R. (1963) Food recognition and predation on opisthobranchs by Navanax inermis (Gastropoda: Opisthobranchia). Veliger 6, 1-9.

Paine R. (1965) Natural history, limiting factors and energetics of the opisthobranch Navanax inermis. Ecology 46, 603-619.

Pennings S.C. (1990) Predator-prey interactions in opisthobranch gastropods: effects of prey body size and habitat complexity. Marine Ecology Progress Series 62, 95-101.

Pennings S.C., Natisch S. and Paul V.J. (2001) Vulnerability of sea hares to fish predators: importance of diet and fish species. Coral Reefs 20, $320-324$.

Rudman W.B. (1971) Structure and functioning of the gut in the Bullomorpha (Opisthobranchia). Journal of Natural History 5, 647 -675.

Rudman W.B. (1972a) A comparative study of the genus Philinopsis Pease 1860 (Aglajidae, Opisthobranchia). Pacific Science 26, 381-399.

Rudman W.B. (1972b) On Melanochlamys Cheeseman 1881, a genus of the Aglajidae (Opisthobranchia, Gastropoda). Pacific Science 26, $50-62$.

Rudman W.B. (1972C) Structure and functioning of the gut in the Bullomorpha (Opisthobranchia). Part 4. Aglajidae. Journal of Natural History 6, 547-560.

Rudman W.B. (1974) A comparison of Chelidonura, Navanax and Aglaja with other genera of the Aglajidae (Opisthobranchia: Gastropoda). Biological Journal of the Linnean Society 54, 185-212.

Rudman W.B. (1978) A new species and genus of the Aglajidae and the evolution of the philinacean opisthobranch molluscs. Biological Journal of the Linnean Society 62, 89-107.

Sleeper H.L., Paul V.J. and Fenical W. (1980) Alarm pheromones from the marine opisthobranch Navanax inermis. Journal of Chemical Ecology 6, 57-70.

Tchang-Si (1934) Contribution a l'étude des opisthobranches de la côte de Tsingtao. Contributions from the Institute of Zoology, National Academy of Peiping 2, 1-139.

Terrence P., Saltin S.H., Davies M.S., Johannesson K., Stafford R. and Williams G. (2013) Snails and their trails: the multiple functions of trail following in gastropods. Biological Reviews 88, 683-700.

Thompson T.E. (1976) Biology of Opisthobranch molluscs. Volume I. London: The Ray Society.

Thompson T.E. (1977) Jamaican opisthobranch molluscs I. Journal of Molluscan Studies 43, 93-140.

Turner T. (1978) Adaptive significance of foot forms and types of locomotion in Opisthobranchs. Master thesis. California State University, East Bay, Hayward, CA.

Valdés Á., Behrens D. and DuPont A. (2006) Caribbean sea slugs. A field guide to the opisthobranch mollusks from the tropical northwestern Atlantic. Washington, DC: Sea Challengers Natural History Books.

Wägele H. (2004). Potential key characters in Opisthobranchia (Gastropoda, Mollusca) enhancing adaptive radiation. Organisms, Diversity and Evolution 4, 175-188.

Wägele H. and Klussmann-Kolb A. (2005) Opisthobranchia (Mollusca, Gastropoda) - more than just slimy slugs. Shell reduction and its implications on defence and foraging. Frontiers in Zoology 2, 1-18. 
Yonow N. (1992) Observations on the diet of Philinopsis cyanea (Martens) (Cephalaspidea, Aglajidae). Journal of Conchology 34, 199-204.

and

Yonow N. (1994) A new species and a new record of Chelidonura from the Red Sea (Cephalaspidea: Aglajidae). Journal of Conchology 35, 141-147.

\section{Correspondence should be addressed to:}

A. Zamora-Silva

Phylogenetic Systematics and Evolution Research Group,

Department of Natural History, University Museum of Bergen, University of Bergen, PB 7800, 5020-Bergen, Norway email: Andrea.Zamora@um.uib.no 